Man and Nature

L'homme et la nature

\title{
Vital Forces and Vital Laws in Eighteenth-Century French Physiology
}

\section{Elizabeth Haigh}

Volume 4, 1985

URI : https://id.erudit.org/iderudit/1011833ar

DOI : https://doi.org/10.7202/1011833ar

Aller au sommaire du numéro

Éditeur(s)

Canadian Society for Eighteenth-Century Studies / Société canadienne d'étude du dix-huitième siècle

ISSN

0824-3298 (imprimé)

1927-8810 (numérique)

Découvrir la revue

Citer cet article

Haigh, E. (1985). Vital Forces and Vital Laws in Eighteenth-Century French Physiology. Man and Nature / L'homme et la nature, 4, 1-15.

https://doi.org/10.7202/1011833ar

Copyright (C Canadian Society for Eighteenth-Century Studies / Sociéte canadienne d'étude du dix-huitième siècle, 1985
Ce document est protégé par la loi sur le droit d'auteur. L'utilisation des services d'Érudit (y compris la reproduction) est assujettie à sa politique d'utilisation que vous pouvez consulter en ligne.

https://apropos.erudit.org/fr/usagers/politique-dutilisation/ 


\section{Vital Forces and Vital Laws in Eighteenth-Century French Physiology}

During the course of the eighteenth century, physiology developed as a distinct science with clear epistemological limits. At the century's beginning, there were merely theories concerning the nature of living bodies and their processes. At its end, there existed a delimited field preoccupied with functions and forces specific to vital phenomena. In 1700, European physicians tended to choose mechanistic models to explain organic functions while assigning the regulation of the body to a soul or other principle heterogeneous to its substance. They did so largely because they took it as axiomatic that matter, including that in a living organism, is inert, moving only in response to an externally applied force. The development of physiology is, in its most fundamental sense, the offspring of a challenge to that assumption about material nature.

By the middle of the eighteenth century, a number of physicians and naturalists were describing vital activity as though its source was in the bodily parts themselves. Among the most important of these were Albrecht von Haller and Théophile de Bordeu, the latter being the first spokesman for what became known as the Montpellier school. They based their widely influential theories of organic function on the study of the properties of irritability and sensibility which were not reducible to physical or chemical principles, but which were seen to be the instruments of bodily activity. Haller located them in minute fibres while 
Bordeu claimed they belong to individual organs. Their particular kind of approach is the subject of this paper. It culminated in the work of Xavier Bichat who, at the turn of the nineteenth century, located vital properties in distinct tissues which he identified as bodily elements. Bichat's influential work was the epitome, in France, of a phenomena loosely labelled 'vitalism.' At the same time, it was a dead end, owing to his thesis that nature encompasses two sets of forces, two sets of laws and finally two distinct sciences.

Bichat died in Paris in 1802 in his thirty-first year, most probably of an infection acquired while performing a post-mortem examination of a fever victim. He had come to the capital from Languedoc some eight years before during the height of the revolutionary Terror. His total medical training amounted to a mere eight-month long apprenticeship to the Hôtel-Dieu's greatest surgeon, Pierre-Joseph Desault. It was long enough, however, to generate a great enthusiasm for anatomical and physiological study such that, by the end of his brief life, Bichat ${ }^{1}$ had acquired a very considerable reputation. On hearing of Bichat's death, the first Consul Napoleon Bonaparte instructed his Minister of the Interior to place a marble monument in honour of his memory in the Hôtel-Dieu, Paris' chief hospital. Today, a Parisian hospital and a street both bear his name, he is represented on the pediment of the Pantheon, and his life-size statue stands alone in the courtyard of the Faculty of Medicine in Paris. It is eloquent testimony to the esteem accorded him. And this at a time when Parisians tended to be less generous in their judgement of French 'provincials' than they are today. ${ }^{2}$ It is interesting to consider, therefore, what it was that this particular young man achieved which catapulted him to a position as the most important writer on anatomical and physiological subjects in France.

His reputation rested largely upon two books, the Recherches physiologiques sur la vie et la mort which appeared in 1800, and a four volume Anatomie générale appliquée à la physiologie et à la médecine published just one year later. The former was an eloquent vitalist statement which synthesized the most advanced contemporary notions about the nature of the living body and its functions. The latter used these notions as a substructure for a painstaking anatomical analysis of living matter into twenty-one distinct tissues which, Bichat contended, variously combine to form the organs and parts of the body. The tissue was an organic counterpart of Lavoisier's chemical elements.

Broadly defined, vitalism is the notion that living systems possess some entity or force which imparts to them powers denied to inanimate bodies. The term is at best imprecise, legions of persons at least as far back as Aristotle qualifying on that definition as 'vitalists.' Its opposite is 
mechanism which has as its basic view the notion that a biological event is composed of non-biological occurrences, the body being ultimately reducible to physico-chemical phenomena. ${ }^{3}$ While most vitalists before Bichat allowed physics and chemistry a kind of auxiliary status to physiology, assuming that living organisms abide by physical laws even if they transcend them, Bichat took the vitalist position to its limit claiming that inorganic sciences could throw virtually no light upon living processes. For him, the study of organic function constituted an absolutely unique science possessing its own forces and laws and concerning itself with activities and processes which have no counterpart in the inorganic world. Accordingly, he argued that any attempt to apply physical or chemical principles to organisms is a specious undertaking. ${ }^{4}$

In Vie et mort, Bichat defined life as 'l'ensemble des fonctions qui résistent à la mort.' ${ }^{\prime 5}$ Prosaic and tautological though it may be, the definition reveals that Bichat saw the living body as an organic unit besieged by subversive and destructive forces belonging to the surrounding inorganic world. While life persists, its transitory forces are dominant over enduring physical and chemical ones making the latter virtually of no effect. It is by means of these combative vital forces, he argued, that an organism grows, reproduces itself, is nourished and responds to its environment. They leave the body gradually if death is natural or lingering, or they flee quickly if it is accidental or sudden. After death, the physical forces, such as attraction and gravitation, reassert their dominance. The organism decomposes, gradually becoming one with the simpler, more predictable realm of inorganic nature.

His conviction about the two realms of nature derived from the commonplace observation that prediction in the inorganic world is more reliable than in the organic one. He wrote as follows:

Les lois physiques sont constantes, invariables; elles ne sont sujettes ni à augmenter ni à diminuer. Dans aucun cas une pierre ne gravite avec plus de force vers la terre qu'à l'ordinaire; dans aucun cas le marbre n'a plus d'élasticité, etc. Au contraire, à chaque instance la sensibilité, la contractilité s'exaltent, s'abaissent et s'altèrent: elles ne sont presque jamais les mêmes.

Il suit de là que tous les phénomènes physiques sont constamment invariables, qu'à toutes les époques, sous toutes les influences, ils sont les mêmes; que l'on peut, par conséquent, les prévoir, les prédire, les calculer .... Au contraire, toutes les fonctions vitales sont susceptibles d'une foule des variétés. Elles sortent fréquemment de leur degré naturel; elles échappent à toute espèce de calcul; il faudroit presque autant de formules que de cas qui se présentent. On ne peut rien prévoir, rien prédire, rien calculer dans leurs phénomènes: 
nous n'avons sur eux que des approximations, le plus souvent mêmes incertaines. ${ }^{6}$

It was a consistent theme in his writing and in his teaching. In some extant lecture notes prepared for a private anatomy course, for example, Bichat conceded the accuracy of Alfonse Borreli's basic calculations of forces in his application of mechanics to his study of muscular action. But he rejected the whole exercise as worthless since it was grounded in the assumption of predictability. So he reminded himself to insister ici sur l'inutilité des mathématiques. ${ }^{7}$

Bichat identified five distinct vital properties, three deriving from sensibility or the property of tissue to perceive needs, directions or stimuli, and two from contractility or the ability of tissues or the smallest bodily parts to move in response to sensibility. Two of the properties exist entirely beneath the level of consciousness. ${ }^{8}$ Seeing them as counterparts of attraction, gravitation, elasticity and so on, Bichat believed that they operate in accordance with 'vital laws' which he went on to outline. ${ }^{9}$

Within a very few years after his works were published, Bichat's position on behalf of the separation of physiology from physics was orthodoxy in France. Taken to be the most advanced notion concerning the science of life, it was taught to French medical students for at least forty years after Bichat's death. ${ }^{10}$ As well as being an assiduous experimenter and observer, Bichat was an accomplished synthesizer of the theoretical currents and innovations which preoccupied his fellow physicians and their predecessors. Not surprisingly, therefore, many of the elements which composed his vital theory were but part of his professional ambience. Although vitalism is as old as speculation about the nature of life, Bichat belonged to a group whose language was developed about the middle of the eighteenth century largely in reaction to a mechanical imagery which had prevailed for some hundred years. By the second quarter of the century, that mechanical language was no longer sufficient to account for the organic phenomena examined by contemporary physicians and natural philosophers. Therefore, Bichat's work is a kind of culmination of French vitalism, best understood as a gleaning from many currents.

Today, a scientist's allegiance to vitalism or mechanism has as much to do with a kind of ideological or metaphysical propensity as with any empirical evidence, as it tends to affect his work little, if at all. In the eighteenth century, however, it was of greater practical consequence, determining the character of the questions he asked of the organism and the nature of the experiments or observations he undertook.

In 1700 , the orthodox European medical man was a mechanist. His im- 
ages of living processes were shaped by an iatromechanical school which had begun to develop its language in the 1660s largely at the hands of persons schooled in the mechanics of Galileo or the philosophy of Descartes. Indeed, virtually all mechanists tended to be dualists of the Cartesian mould. That is, they conceived of the organism as a composite of a material body and an immaterial soul. The mechanical philosophy which had generated iatromechanism held that matter is inert and passive substance devoid of any innate ability to generate motion. When it moved, it did so in response to a force external to its substance. In addition to being a spiritual entity, the soul was considered to be the source of willed, conscious and cognitive activity. Resident in the brain, it was presumed to act on the matter of the body through the medium of animal spirits located in nervous fibres. ${ }^{11}$

As the conceptual and epistemological offspring of mechanical philosophy, iatromechanism was an intricate interweaving of physics and physiology. By the turn of the eighteenth century it became common for writers on the subject to account for muscular motion, glandular function, nervous system activity and so on by resorting to an imagery of sieves, pulleys and pipes. For example, Europe's preeminent teacher of medicine, Hermann Boerhaave, wrote the following:

The solid Parts of the human Body are either membranous Pipes, or Vessels including the Fluids, or else Instruments made up of these and more solid Fibres, so formed and connected, that each of them is capable of performing a particular Action by the Structure, whenever they shall be put in Motion; we find some of them resembe Pillars, Props, Cross-Beams, Fences, Coverings, some like Axes, Wedges, Leavers, and Pulleys; others like Cords, Presses or Bellows; and others again like Sieves, Strainers, Pipes, Conduits and Receivers; and the Faculty of performing various Motions by these Instruments is called their Functions; which are all performed by Mechanical Laws; and by them only are intelligible. ${ }^{12}$

Such assumptions and the kind of investigative work they engendered were taken to be akin to those of physicists and other natural philosophers who had recently achieved spectacular breakthroughs in their study of nature. The principles the physicists identified and the laws they discovered were so breathtakingly successful in their ability to explain and to predict phenomena that physicians tried to emulate them to provide their own investigations with similar achievements. So it was that for some decades, those persons who studied organisms would try to account for physiological processes by resorting to the sorts of images we see in the quotation from Boerhaave. 
But while sieves, pulleys and such can be made to account for many isolated activities and functions, they are insufficient for interpreting the apparently purposeful activities of organisms. A mechanist's explanation of the various stages of digestion, for example, was bound to be far more persuasive than his interpretation of the process of nourishment. He inevitably ran the risk of oversimplifying such complex and integrated processes as adaptation, coordination, development and growth. So it was that animistic and especially vitalisitc imagery came to be seen as a far more fruitful means of ordering one's thoughts about living phenomena, and came to displace iatromechanism.

The first substantial challenge to Boerhaave's type of mechanism came from his contemporary, the German physician George Ernst Stahl (1659-1734), an animist who contended that all living motion, unconscious as well as willed, has its source in the soul or anima. Like the mechanists, animists were dualists who held that the matter of the body depended upon an external mover. Other vitalists, sharing this same view of matter, postulated some specific life-conferring principle which was supposed to coexist with the body and the soul as a kind of third substance overseeing the automatic and unconscious acts of life. By the mid-eighteenth century, however, a new type of vitalism emerged. Its exponents argued that vital properties reside in the bodily parts themselves. They assumed that such properties as sensibility and contractility to which one can ultimately assign all living activity, are by-products of organic organization, immanent in living substance. It was a conceptual innovation of some consequence for it would free persons from an elusive search for immaterial and insubstantial principles, allowing them to turn their attention directly to the organism itself..$^{13}$ It is, of course, to their number that Bichat and his intellectual predecessors belonged.

There is, for example, the case of the worldly and ambitious Theophile de Bordeu (1722-1776) who earned the title of médecin-chirurgien from the ancient Medical University of Montpellier in 1744. He encountered unorthodoxy while he was still a student, for one of his memorable instructors was François Boissier de Sauvages, a flamboyant rebel whose animist teaching was provoking considerable controversy in the hitherto stolidly mechanistic school. Persuaded at least by Sauvages' antimechanism if not by his animism, Bordeu gradually evolved an elegant and persuasive alternative to both mechanism and animism. In so doing, he owed much to such seventeenth century writers as Jean Baptiste Van Helmont, Francis Glisson, and William Harvey, all of whom had written at length on the subject of the reactivity of living fibres, but whose speculations had been temporarily eclipsed by those of the iatromechanists. 
In Bordeu's mature physiological theory, vital function was associated with an active force of sensibility which he believed is distributed among the organs of the body. This sensibility activates an accompanying force of irritability or contractility which in turn provokes vital activity. His most important work on the subject was Recherches anatomiques sur la position des glandes et leur action of 1752 in which the various glands served as models for describing the functions of all organs. ${ }^{14}$ With a series of painstaking and impeccable experiments, he demolished prevailing mechanistic theories which prescribed glands as complicated sieves and filters whose products are extruded by pressure. ${ }^{15} \mathrm{He}$ went on to account for secretion and excretion of unique humours by claiming that each gland possesses a particular sensibility which regulates its own special activity. Finally, he described the organism as a collection of organs each with its particular and separate life or sensibility which is finally integrated into its total life. The soul remained in Bordeu's system as a cognitive and spiritual entity, but it was no longer needed to account for the activity of the parts.

Bordeu was to be the most eminent representative of what became known simply as the Montpellier school. Its influence in France was considerable at least partly because Denis Diderot (1713-1784) became persuaded that the notions of sensibility and irritability were the most advanced explanations for organic activity. Consequently, he solicited articles from persons conversant with the language of the Montpellier school for the Encyclopédie, making it the instrument for the propagation of the new physiology. Bordeu himself contributed at least two long articles, 'Pouls'16 and 'Crise' in which he traced the explanation of both phenomena as far back as Hippocrates. Articles on 'Sensibilité' and 'Sécrétion,' both of which faithfully follow Bordeu's ideas, were written by the Montpellier professor, Henri Fouquet. One of the most prolific contributors was a Dr. Ménuret de Chambaud, also of the Montpellier school, who contributed more than forty articles to the last ten volumes of the Encyclopédie.

French physicians were not alone, of course, in promulgating the new physiology of the reactivity of the parts. The best known of all work on the subjects of sensibility and irritability is surely that of the peevish, pious Swiss physician Albrecht von Haller (1698-1777), Bordeu's professional contemporary. Haller is best known for his extensive attempts to observe and to localize the properties in the various organs and parts. But he acknowledged the existence of sensibility in a part only when an animal gave an indication of having felt a stimulus, and irritability only when it produced a perceptible motion. ${ }^{17} \mathrm{He}$ found that they exist in a kind of inverse relationship in the parts, the most mobile often exhibiting 
the least sensibility. Since we do not perceive the activity of our glands, Haller unjustly dismissed Bordeu's work on those organs, remarking merely that glands generally receive few nerves and have little sensation. ${ }^{18}$ Individual definitions of sensibility aside, however, Haller also speculated about the indwelling ability to motion which apparently resides in living organs:

There resides in the heart a kind of impatience to stimulus .... That motion is peculiar to the heart itself; coming neither from the brain, nor the soul; seeing that it remains in a dead animal even when the heart is torn out of the breast; neither can it, by any act of the will, be made either quicker or slower. ${ }^{19}$

\section{And elsewhere:}

It is so certain that motion is produced by the body alone that we cannot even suspect any motion to arrive from a spiritual cause, besides that which we see is occasioned by the will. ${ }^{20}$

Therefore, by the mid-eighteenth century, the notion that sensation and activity are, under certain conditions, immanent in matter was commending itself to more and more people.

One of the most interesting exponents of that position was the outrageously outspoken materialist, Julien Offray de La Mettrie (1709-1751), who took great delight in offending his fellow physicians. He developed the then current notion of the reactivity of the bodily parts to the point where he denied the existence of a vital principle or soul altogether. In 1746, in Histoire naturelle de l'âme, he argued that thought, volition, and all purposive motions of the body are merely the products of physical organization. The Parlement of Paris consigned the book to the flames and La Mettrie fled a hostile France for a more liberal Holland. His L'Homme machine of the following year, however, appalled even the tolerant Dutch. The abuse heaped upon him reached hysterical proportions as the scholarly world recoiled from his allegedly atheistic theses. In fact, however, by dispensing altogether with the soul as an explanation of the body, La Mettrie had moved a small consistent step beyond Bordeu and Haller claiming that all bodily processes, rational, conscious and unperceived alike, belong to matter:

... toutes les facultés de l'Ame dépendent tellement de la propre Organisation du Cerveau \& de tout le Corps, qu'elles ne sont visiblement que cette Organisation même .... L'Ame n'est donc qu'un vain terme dont on n'a point d'idée, \& dont un bon Esprit ne doit se servir que pour nommer la partie qui pense en 
nous. Posé le moindre principe de mouvement, les corps animés auront tout ce qu'il leur faut pour se mouvoir, sentir, penser, se repentir, \& se conduire en un mot dans le Physique, \& dans le Moral qui en dépend. ${ }^{21}$

To demonstrate the existence of this motive principle in living flesh, La Mettrie remarked that all animal muscle palpitates after death; muscles separated from the body contract when they are pricked or otherwise stimulated; intestines retain their peristaltic motion for a considerable time after death or outside the body; a simple injection of warm water reactivates heart muscle, and so on. Like many of his contemporaries he was fascinated by a remarkable little creature called a polyp which superficially resembles a plant more than an animal. A naturalist, Abraham Trembley, had observed that under certain circumstances, a part separated from the creature can regenerate a complete new polyp in a few hours. ${ }^{22}$ It had come to be a cause célèbre whose regenerative capacity lent itself to a variety of interpretations. For such as La Mettrie and for monists in general, the polyp's remarkable ability spoke eloquently on behalf of a motive force resident in the parts themselves. It could not help but confirm La Mettrie in his conviction that life has nothing to do with a vital or spiritual principle.

La Mettrie's man-machine has frequently been interpreted as an extrapolation of Descartes' beast-machine. Indeed, the very title of the work invites that interpretation. However, a large conceptual gulf separates their ideas for, as we have seen, La Mettrie utterly rejected the insubstantial realm of the soul. The machine he described is composed not of inert, brute matter but of substance throbbing with activity. We read, for example, that 'Le corps humain est une Machine qui monte ellemême ses ressorts; vivante image du mouvement perpetuel. ${ }^{23}$ In another instance, 'Entrons dans quelque détail de ces ressorts de la Machine humaine. Tous les mouvemens vitaux, animaux, naturels, \& automatiques se font par leur action.' ${ }^{24}$ (p. 182 of $l^{\prime}$ Homme machine) Near the end of the work, he affirmed, '... que l'Homme est une Machine; \& qu'il n'y a dans tout l'Univers qu'une seule substance diversement modifée. 25

It could be that La Mettrie's aggressive atheism appalled his contemporaries above all because they recognized him as a prodigal intellectual relation. He delighted in maliciously pointing out that he was one of them. ${ }^{26}$ For example, he effusively dedicated L'Homme machine to the humourless Haller, praising him extravagantly in the preface and claiming him as both inspiration and teacher. ${ }^{27}$ Ideology aside, however, La Mettrie was quite correct to see a connection between their ideas about organic matter and organic functions.

Other persons who held similar ideas tended to expound them more 
judiciously. One of the most interesting among them is Diderot who not only encouraged the viewpoint of the Montpellier school as we have seen, but who engaged in rather more freewheeling speculations of his own concerning the nature of life, consciousness and cognition. Around 1753, Diderot subscribed to the viewpoint of the great naturalist Buffon who believed that nature actually contains two kinds of matter - one living and one inert. But shortly thereafter, we find Diderot raising pertinent philosophical questions in such a way as to invite a different interpretation of the evidence:

Mais comment se peut-il faire que la matière ne soit pas une, ou toute vivant ou toute morte? Et la matière morte est-elle toujours et' réellement morte? La matière vivante ne meurt-elle point? La matière morte ne commence-t-elle jamais à vivre? ${ }^{28}$

In 1759 , in a private letter, he remarked that it is absurd to claim that 'la particule $a$ placée à gauche de la particule $b$ n'avoit point la conscience de son existence, ne sentoit point, étoit inerte et morte' but if $a$ is to the right of $b$ 'le tout vit, se connoit, se sent. ${ }^{2}{ }^{29} \mathrm{He}$ asked another correspondent to consider the fact that inert matter which is eaten becomes incorporated by the organism and nourishes it. It must be, he has concluded by at least 1765 , that sensibility is a universal property of matter. He wrote as follows:

La pensée est le résultat de la sensibilité, et [que], selon moi, la sensibilité est une propriété universelle de la matière; proporiété inerte dans les corps bruts ... propriété rendue active dans les mêmes corps par leur assimilation avec une substance animale vivante. ${ }^{30}$

This theme was elegantly developed in the Rêve de d'Alembert of 1769 in which Diderot made Bordeu his mouthpiece, but made him express ideas which went well beyond those which we read in Bordeu's own writings. By so doing Diderot made it clear that it was Bordeu's notions which gave him the idea which led to this theoretical position.

The visionary quality of Diderot's views is exciting if one is pleased with the notion of a universe pulsating with ubiquitous vitality. Matter, it follows, is a panorama of apparently inert but sensitive points congealing to form objects some of which are living, conscious beings. Life is continually emerging from its potential state so that soil, stone, plants and animals form an intricate and interconnected mass of matter changing its form in such a way that neither birth nor death has any ultimate meaning. The Rêve is a masterpiece of materialistic vitalism. If one 
adopts Diderot's thesis, then it follows that the natural philosopher is not limited to studying life exclusively with the tools of physics and chemistry. But neither is he sent questing after an ephemeral and elusive soul or vital principle. It must have been heady stuff even for Diderot in 1769. Perhaps mindful of the abuse to which La Mettrie had been subjected, he did not publish the Rêve, which only appeared posthumously. ${ }^{31}$

Restricted much more by his empirical evidence, the notions of Bichat the anatomist were much more pedestrian. Keeping his eyes fixed on organic specimens, he did not let his imagination soar off on such freewheeling tangents as univeral sensibility. Indeed, his very view of an organism as a kind of besieged island in a sea which would destroy it precluded such a notion. Bichat is more directly the heir of Haller and of Bordeu and other members of the Montpellier school. In the final analysis, he had more immediate influence at least in the medical world not least because his views were immediately published and approved. Most importantly, his vitalist convictions had immediate implications for the teaching and possibly for the practice of medicine, but especially for the development of physiological theory.

\section{ELIZABETH HAIGH}

Saint Mary's University

\section{Notes}

1 Bichat's bibliography can be recreated from a number of sources, the most recent being by Maurice Genty, 'Xavier Bichat, (1771-1802),' Biographies médicales et scientifiques, ed. Pierre Huard (Paris: Roger Dacosta, 1972). Other selected sources are Jacques Coquerelle, Xavier Bichat, (1771-1802) (Paris: A. Maloine, 1902); Pierre Blanchard, ed., Centenaire de la mort de Xavier Bichat (Paris: Librarie Scientifique et Littéraire, 1903) and Mathieu-François Buisson, 'Précis Historique sur Marie-François-Xavier Bichat', 'Traité d'anatomie descriptive, 5 vols. (Paris: Brosson, Gabon et Cie, 1802), III, vii-xxviii.

2 Before the Revolution, persons trained outside, unless they enjoyed royal patronage, could not practice medicine in the capital without undergoing extensive examination by the Faculte de Paris. After a period of ideologically-based confusion about how all education should be structured in post-revolutionary France, medical training was massively remodelled. These subjects are discussed in many places including Theodore Puschman, A History of Medical Education (New York: Hafner, 1966), facsimilie of 1891 edition; David Vees, Medical Revolution in France, 1789-1796 (University of Florida, 1975) and Toby Gelfand, Professionalizing Modern Medicine: Paris Surgeons and Medical Science and Institutions in the 18th Century (Westport, Conn: Greenwood Press, 1980). 
3 In the eighteenth century, at least three broad categories of vitalists or antimechanists can be distinguished. Stahlians or animists argued that all living activity derives ultimately from a rational or immaterial soul or anima. Others like Paul-Joseph Bartez of Montpellier postulated some specific life-conferring principle which coexists with the material body and the immaterial soul and which oversees the automatic and unconscious acts of life. Still others, frequently labelled 'organicists', argued that vital activity is intrinsic to the matter of the body itself. For analyses of their ideas, see François Duchesneau, La physiologie des lumières. Empiricisme, modèles et théories (The Hague, Boston, London: Martinus Nijhoff, 1982); Lester S. King, The Philosophy of Medicine (Cambridge, Mass.: Harvard University Press, 1978); Martin S. Staum, Medical Component of Cabanis' science of man (Princeton: Princeton University Press, 1981); and Elizabeth Haigh, Xavier Bichat and the Medical Theory of the Eighteenth Century (London: Wellcome, 1984).

4 Which is not to deny, of course, that mechanical processes affect physiological ones. A very recent paper on this subject is by Geoffrey Sutton, 'The Physical and Chemical Path to Vitalism: Xavier Bichat's Physiological Researches on Life and Death,' Bull. Hist. Med., 58 (1984) 53-71. Sutton demonstrates that in a particular group of experiments, Bichat undertook to demonstrate that the heart, in addition to distributing nourishment to the bodily parts, has the function of sustaining the tissues by mechanically agitating them.

5 Xavier Bichat, Recherches physiologiques sur la vie et la mort (Paris: Brosson, Gabon et Cie, 1800), p. i.

6 Xavier Bichat, Anatomie générale appliquée à la physiologie et à la médecine, 4 vols. (Paris: Brosson, Gabon et Cie, 1801), I, pp. lii-liii.

7 Xavier Bichat, 'Discours sur l'étude de la phisiologie,' ed. A. Arène, Arch. Anthr. Crim., 26 (1911), 170.

8 The five properties were labelled, animal sensibility, organic sensibility, animal contractility, sensible organic contractility, and insensible organic contractility. Organic sensibility and insensible organic contractility are imperceptible to a conscious organism. See Bichat, Vie et mort, op. cit., p. 130 and Anatomie général, I, pp. xi-xiii, lxxii-lxxix.

9 For a more extensive discussion of Bichat's work, see Duchesneau, pp. 431-76, and my Xavier Bichat.

10 Claude Bernard related, for example, being reprimanded for questioning the assumption that living nature is infinitely variable and hence fundamentally different from the inorganic world. Claude Bernard, Lectures on the Phenomena of Life Common to Animals and Plants, trans. by Hebbel E. Hoff, Roger Guillemin, and Lucienne Guillemin (Springfield, Ill.: Charles C. Thomas, 1974), p. 41.

11 The most famous speculation about animal spirits serving as a medium of communication between immaterial and material elements is found in René Descartes, Discours de la Méthode. Their existence was, however, very widely assumed. The mechanist Friedrich Hoffman, for example, wrote: The animal spirits are not the vital principle or soul itself but the soul uses them as instruments for achieving its function. The functions of the soul are to move the spirits and to direct them to produce particular motions.' Fundamenta medicinae (London: MacDonald, 1971), pp. 11-13. 
12 Hermann Boerhaave, 'The nature and principles of physiology,' Dr. Boerhaave's academical lectures on the theory of physic being a genuine translation of his Institutes as dictated to his students at the University of Leyden, 6 vols. (London: W. Innys, 1757-73), I, 85.

13 This process is discussed broadly and with great erudition by Duchesneau, $o p$. cit.. He argues that the anti-mechanism of eighteenth-century persons established the epistemological frontier between the objects of physics and those of physiology, making the latter science possible.

14 Elizabeth L. Haigh, 'Vitalism, the soul and sensibility: The physiology of Théophile de Bordeu,' J. Hist. Med., 31 (1976), 30-41.

15 According to Bordeu, Boerhaave's theory was the one generally accepted in the mid-eighteenth century. Though he admitted that glands are more than mere sieves, Boerhaave predictably still tried to understand their complex operations mechanistically:

Hence the Humours will be various according to the Discharge of the Artery from the Heart, its Situation with respect to the Heart and the Trunk from whence it arises, its different Complications \& Number of Ramifications before it terminates, the different Velocity of the Blood moving through it, the Proportion that the single Branch bears to its Trunk, the different propelling Forces, both external and internal, which discharge the Humours, the different Time of its standing in the common Cavity or Receptacle, \& the various Passages it goes through, from whence making new Changes, with the different Degree of Absorption or Exhalation of the more fluid Degree of Absorption or Exhalation of the more fluid Parts from the secreted Juice; all these Causes, I say, concur to produce the vast variety of Humours observed in the several Parts of the Body, from that one common Mass the Blood, whose Particles are thus variously sorted, separated, \& combined in a wonderful Manner.

Herman Boerhaave, 'Of the different structure of the glands,' II, 234. Once secreted, the glandular humour had to be excreted into the body. In a discussion of the role of the salivary glands in digestion, he remarked that he believed that the salivary juices are extruded into the mouth by jaw movements during chewing. Boerhaave, 'Of the origin, nature and mixture of the saliva with the ailments,' I, 134-156.

16 Bordeu published a monograph on the subject of the pulse also. Théophile de Bordeu, Recherches sur le pouls in Oeuvres complètes de Bordeu, 2 vols. (Paris: Caille et Ravier, 1818).

17 He wrote as follows:

I call that part of the body irritable which becomes shorter upon being touched; very irritable if it contracts upon a slight touch, and the contrary if by a violent touch it contracts but little. I call that a sensible part of the body, which upon being touched transmits the impression of it to the soul; and in brutes, in whom the existence of the soul is not so clear, I call those parts sensible, the irritation of which occasions evident signs of pain and disquiet in the animal. On the contrary, I call that insensible, which being burnt, tore, pricked, or cut till it is destroyed, occasions no sign of pain nor convulsion, nor any sort of change in the situation of the body. 
Albrecht von Haller, First lines of physiology, translated from Latin and printed under the inspection of William Cullen, 2 vols. in 1, reprint of 1786 edition (New York: Johnson Reprint, 1966), pp. 658-59.

18 ibid., p. 67. Bordeu responded graciously to Haller's criticism in his Recherches sur l'histoire de la médecine, merely pointing out that their respective definitions of irritability were not the same. Théophile de Bordeu, II, 668-69.

19 Haller, I, Sect. CII, pp. 59-60. The emphasis in the passage is Haller's own.

20 Albrecht von Haller, 'A dissertation on the sensible and irritable parts of animals' (London: J. Nourse, 1755), a contemporary translation from Latin with introduction by Owsei Temkin, Bull. Hist. Med., 4 (1936), 651-99.

21 Julian Offray de la Mettrie, L'Homme machine, ed. Aram Vartanian, (Princeton: Princeton University Press, 1960), p. 180.

22 Aram Vartanian, 'Trembley's polyp, La Mettrie, and eighteenth century French materialism,' J. Hist. Ideas, II (1950), 259-86.

23 La Mettrie, p. 154.

24 ibid., p. 182.

25 ibid., p. 197.

26 For example, a few months before L'Homme machine was completed, La Mettrie heard Jerome Gaub, Boerhaave's successor at Leyden University, read a paper on the subject of the relationship between the mind and the body. He proceeded from the assumption that mental phenomena are physically regulated. La Mettrie borrowed many examples from Gaub to illustrate his materialistic theses. A Christian, Gaub was sorely disturbed by this apparent affinity between their respective notions. In 1763, he referred as follows to La Mettrie's presence at the talk he had delivered some sixteen years earlier:

I do indeed regret bitterly that a little Frenchman ... brought forth a repulsive offspring, to wit, his mechanical man, not long after sitting before this chair and hearing me speak, and did this in such a way that it seemed to many people that I had furnished him with, if not sparks for his flame, at least matter for embellishing his montrosity.

From L.J. Rather, Mind and body in eighteenth century medicine, a study based on Jerome Gaub's De regimine mentis (London: Wellcome, 1965), pp. 115-204. Gaub's reaction to La Mettrie's work is also described by Aram Vartanian, 'Introduction,' L'Homme machine, pp. 90-92. Vartanian quotes from a letter from Gaub to Charles Bonnet concerning that same 1747 lecture. Referring to La Mettrie's attendance there, he wrote that 'Des esprits malins en tirent des conséquences irreligieuses.'

27 La Mettrie dedicated L'Homme machine to Haller with the following words:

C'est le plaisir que j'ai eu à composer cet ouvrage, dont je veux parler; c'est moi-même, \& non mon livre que je vous addresse, pour m'éclairer sur la nature de cette sublime Volupté de l'Etude. Tel est le sujet de ce Discours. Je ne serois pas le premier Ecrivain, qui, n'ayant rien à dire, pour réparer la Stérilité de son Imagination, auroit pris un texte où il n'y en eut jamais. Ditesmoi donc, Double Enfant d'Apollon, Suisse Illustre, Fracastor Moderne, vous 
qui savez tout à la fois connoître, mesurer la Nature, qui plus est la sentir, qui plus est encore l'exprimer; savant Médecin, encore plus grande Poëte, dites-moi par quels charmes l'Etude peut changer les Heures en momens; quelle est la Nature de ces plaisirs de l'Esprit, si différens des plaisirs vulgaires .... Mais la lecture de vos charmantes Poësies m'en a trop pénétré moi-même, pour que je n'essaie pas de dire ce qu'elles m'ont inspiré. L'homme, considéré dans ce point de vüe, n'a rien d'étranger à mon sujet (p. 143).

Haller wrote about L'Homme machine as follows:

The deceased M. de la Mettrie has made Irritability the basis of the system which he advanced against the spirituality of the soul; and after saying that Stahl and Boerhaave knew nothing of it, he has the modesty to assume the invention to himself, without ever having made the least experiment about it. But I am certainly informed that he learnt all he knew about it from a young Swiss with whom I am not acquainted: who never was my pupil, nor is he a physician, but he has read my works, and seen some of the famous Albinus's experiments and upon these La Mettrie built his impious system, which my experiments totally refute. For if Irritability subsists in parts separate from the body and not subject to the Command of the soul, if it resides every where in the muscular fibres and is independent of the nerves, which are the satellites of the soul, it is evident, that it has nothing in common with the soul, and it is absolutely different from it; in a word, that neither Irritability depends upon the soul, nor is the soul what we call Irritability in the body. 'A dissertation on the sensible and irritable parts of animals,' op.cit., pp. 695-696.

28 Denis Diderot, Pensées sur l'interprétation de la nature in Oeuvres complètes, 15 vols. (Paris: Le Club Français du Livre, 1969), II, p. 770. The Pensées are discussed by Jacques Roger, Les sciences de la vie dans la pensée française du XVIIIe siècle (Paris: Armand Colin, 1971), pp. 599-614; and by Arthur M. Wilson, Diderot (New York: Oxford University Press, 1962), pp. 187-198.

29 Denis Diderot, 'Lettre du 15 octobre 1759 à Sophie Volland,' in Oeuvres complètes, III, pp. 815-21. Quoted by Jacques Roger, p. 617.

30 Denis Diderot, 'Lettre du 10 octobre 1765 à Monsieur Duclos,' in Oeuvres complètes, V, 949-52. Quoted by Jacques Roger, p. 617.

31 Materialism in British natural philosophy of the eighteenth century has been strenuously studied. Two major works dealing with topics about the nature of matter are Robert E. Schofield, Mechanism and Materialism: British Natural Philosophy in an Age of Reason (Princeton: Princeton University Press, 1970) and John W. Yolton, Thinking Matter: Materialism in Eighteenth Century Britain (Minneapolis: University of Minnesota Press, 1983). 